\title{
Underground mining method assessment using decision-making techniques in a fuzzy environment: case study, Trepça mine, Kosovo
}

\author{
Gzim Ibishi $^{1 * \otimes(\odot)}$, Mahmut Yavuz ${ }^{2 \otimes}$, Melih Genis $^{3 \otimes}$ \\ ${ }^{1}$ Mitrovica Isa Boletini University, Mitrovica, 40000, Kosovo \\ ${ }^{2}$ Eskisehir Osmangazi University, Eskisehir, 26000, Turkey \\ ${ }^{3}$ Zonguldak Bulent Ecevit University, Zonguldak, 26000, Turkey \\ *Corresponding author: e-mail gzim-ibishi@hotmail.com, tel. +38344176357
}

\begin{abstract}
Purpose. The purpose of this paper is to reevaluate the currently used underground mining method with the intention to verify if cut-and-fill stoping method is appropriate for deep future excavation mining levels $>800 \mathrm{~m}$ below the ground sur-face.

Methods. Decision-making methods i.e., Analytical Hierarch Process (AHP) and Fuzzy Multi-Attribute Decision-making Methods (FMADM), and UBC selection tool are implemented.

Findings. According to UBC approach six alternatives - Block Caving, Cut-and-Fill Stoping, Sub-level Caving, Sub-level Stoping, Square Set Stoping, and Top Slicing have been considered as technically feasible alternatives. Results shows that cutand-fill stoping method is the optimal mining method for deep excavation mining levels. Optimal underground mining method for Trepça mine due to the priority of this alternative $(0.443)$ is the highest value compared with the other alternatives.

Originality. This study attempts to find most suitable underground mining method among the possible alternatives based on AHP and FMADM techniques.

Practical implications. In mine planning and design stage, mining method selection (MMS) for a mineral deposit is one of the most critical and challenging decision that experts have to make mainly based on geological, economical and geotechnical properties of the ore deposit.
\end{abstract}

Keywords: Mining method, UBC method, AHP method, FMADM method, Trepça mine

\section{Introduction}

In mine planning and design stage, suitable underground mining method selection is one of the crucial and challenging activities of mining engineering. Once sufficient information has been collected from geological exploration works of a mineral deposit, mining method selection (MMS) process can begin taking the advantage of engineering knowledge, intuition and past experience [1]. One of the fundamental goals of MMS is to maximize net present value (NPV), maximize the exploitation of the mineral deposit and provide safety working environment for employees [2].

Each mineral deposit is unique and has specific site features meaning that there isn't a single convenient mining method utilized of ore deposit extraction. Generally a set of feasible alternatives are possible. Accordingly, selecting the most optimal mining method is known as multi-criteria decision-making (MCDM) process. The optimal mining method from a set of feasible alternatives is the one that best fits the mining condition and has minimum problems [3].

In the literature, there are many applications of decisionmaking methods in mining operations. Many researchers have presented in a successful way application of the AHP and FMADM methods. [4] solved an underground mining selection problem by using the fuzzy analytic hierarchy process (AHP) and the Yager's method for pair-wise comparison of the criteria. [5] applied the Yager's method to select an underground mining method for an iron deposit in Iran. [2] applied the AHP approach of the UMMS to an underground bauxite mine in Iran. [6] used the AHP method of the UMMS to an underground lignite mine in Turkey. [7] applied the AHP technique of the UMMS to an underground bauxite mine in Iran. [8] applied the AHP and Yager's method to select an appropriate mining method for a chromites mine in Turkey. [9] used the AHP and Yager's method to determine an underground mining method for the Ciftalan lignite mine in Turkey. [10] applied the AHP and Yager's method to select an optimal underground mining method for Nchanga mine in Zambia. [11] applied FMADM (Yager's) method to select the most convenient underground mining method for a chromite mine located at the vicinity of Kayseri Pinarbasi. Due to the fact that the fuzzy set theory is far closer to human's subjective perception and representation, we are inspired to utilize MCDM methods in MMS decisionprocess for a mine. 
The aim of this paper is to select a suitable underground mining method between level $+12 \mathrm{~m}$ and level $-227 \mathrm{~m}$ at Trepça mine. This current study was carried out for the sole purpose of reaching a steady production rate meeting safety requirements during mining operations. Finally, a sensitivity analysis technique is utilized to each mining method.

\section{Methods}

\subsection{The AHP method}

The Analytic Hierarchy Process (AHP) is a MCDM technique which was developed by Thomas Saaty in 1977 [12]. The AHP model helps experts to set priorities and make a decision among the alternatives. This technique utilizes a multilevel hierarchical structure of objectives, main/subcriteria, and possible choices. The fitting data are obtained by utilizing a group of pair-wise comparisons (PWC). Such PWC become used to receive the importance weights of the decision criteria, and the relative performance measures of the alternatives with respect to individual decision criterion. In case the comparisons are not completely consistent, afterwards it provides a technique for improving consistency [13]. After structuring the hierarchy, the judgment comparison matrix is developed according to expert's knowledge and used to estimate the priorities of the elements. The PWC matrix is shown in Equation (1) for maximization problems and Equation (2) for minimization problems [9]:

$$
\begin{aligned}
A & =\left[\begin{array}{cccc}
1 & w_{1} / w_{2} & \ldots & w_{1} / w_{n} \\
w_{1} / w_{2} & 1 & \ldots & w_{2} / w_{n} \\
\ldots & \ldots & \ldots & \ldots \\
w_{n} / w_{1} & w_{n} / w_{2} & \ldots & 1
\end{array}\right] ; \\
A & =\left[\begin{array}{cccc}
1 & w_{2} / w_{1} & \ldots & w_{n} / w_{1} \\
w_{1} / w_{2} & 1 & \ldots & w_{n} / w_{2} \\
\ldots & \ldots & \ldots & \ldots \\
w_{1} / w_{n} & w_{2} / w_{n} & \ldots & 1
\end{array}\right],
\end{aligned}
$$

where:

$w_{1}$ - the weight of element 1 ;

$w_{2}$ - the weight of element 2 ;

$w_{n}$ - the weight of element $n$.

The intensity of importance is evaluated utilizing the Saaty's comparison judge Table 1.

\begin{tabular}{|c|c|c|}
\hline Definition & $\begin{array}{l}\text { Relative } \\
\text { intensity }\end{array}$ & Explanation \\
\hline $\begin{array}{l}\text { Equally } \\
\text { preferred }\end{array}$ & 1 & $\begin{array}{l}\text { sub-criteria }(j) \text { and }(k) \text { are equally } \\
\text { important }\end{array}$ \\
\hline $\begin{array}{l}\text { Slightly } \\
\text { preferred }\end{array}$ & 3 & $\begin{array}{l}\text { sub-criterion }(j) \text { is slightly more } \\
\text { important than sub-criterion }(k)\end{array}$ \\
\hline $\begin{array}{l}\text { More } \\
\text { preferred }\end{array}$ & 5 & $\begin{array}{l}\text { sub-criterion }(j) \text { is more important } \\
\text { than sub-criterion }(k)\end{array}$ \\
\hline $\begin{array}{l}\text { Strongly } \\
\text { preferred }\end{array}$ & 7 & $\begin{array}{l}\text { sub-criterion }(j) \text { is strongly more } \\
\text { important than sub-criterion }(k)\end{array}$ \\
\hline $\begin{array}{l}\text { Absolutely } \\
\text { preferred }\end{array}$ & 9 & $\begin{array}{l}\text { sub-criterion }(j) \text { is absolutely more } \\
\text { important than sub-criterion }(k)\end{array}$ \\
\hline $\begin{array}{l}\text { Intermediate } \\
\text { values }\end{array}$ & $2,4,6,8$ & compromise is needed \\
\hline
\end{tabular}

Table 1. Numerical scale of AHP model

In a study by [1], the fundamental steps engaged in this methodology are outlined as following:
Step 1: State the problem.

Step 2: Expand the target of the problem.

Step 3: Determine the criteria that affect the behavior.

Step 4: Construct the problem in a hierarchy of different levels.

Step 5: Compare each element in the corresponding level and calibrate them on the numerical scale.

Step 6: Perform calculations to find the maximum eigenvector, consistency index (CI), consistency ratio (CR), and normalized values for each criteria or alternative.

$$
\lambda_{\max }=\frac{1}{n} \sum_{i=1}^{n}\left\{\frac{\sum_{i=1}^{n} a_{i j} \cdot w_{j}}{w_{i}}\right\},
$$

where:

$\lambda_{\max }-$ the principal eigenvector;

$n$ - the matrix size;

$a_{i j}$ - an element of pair-wise comparison matrix;

$w_{j}$ and $w_{i}-$ the $j^{\text {th }}$ and $i^{\text {th }}$ element of values of eigenvector, in each instance.

$$
\begin{aligned}
& C I=\frac{\lambda_{\max -n}}{n-1} ; \\
& C R=\frac{C I}{R I},
\end{aligned}
$$

where:

$R I$ - the random indices.

To figure out whether the resulting $C I$ is acceptable, the $C R$ should be calculated. The $C I$ of randomly generated reciprocal matrices from the scale 1-9 is called the $R I$. The ratio of $C I$ to $R I$ for the same order matrix is called the $C R$. $R I$ values are given in Table 2 . In principle, a consistency ratio of 0.10 or less is considered acceptable. This means that the result here is less than ideal. In practice, $C R$ exceeding 0.10 occur usually.

Step 7: If the maximum value of eigenvector, $C I$ and $C R$ are satisfactory then decision is taken based on the normalized values; otherwise the procedure is repeated till these values lie in a wanted range.

\subsection{The fuzzy MADM (Yager's) method}

Multiple Attribute Decision Making (MADM) deals with the problem of choosing an alternative from a set of alternatives, which are defined with respect to different attributes. The experts might define weighting of criteria in order to reflect their importance. Most common ways of expressing the relative importance of criteria are the analytical hierarchy processes and fuzzy versions. The focus of this section is on Yager's method [14]. The Yager method takes into consideration the max-min method of [15]. The weighting process utilizes the exponentials based on the definition of linguistic hedges proposed by [16].

Yager's approach takes into account the maximumminimum principle approach. Accordingly, let $A=\left\{A_{1}\right.$, $\left.A_{2}, \ldots A_{m}\right\}$ be the set of possible alternatives, and $C=\left\{C_{1}\right.$, $\left.C_{2}, \ldots C_{n}\right\}$ be the set of criteria, hence, fuzzy set decision is the crossing point of all criteria:

$$
\mu_{D}(A)=\min \left\{\frac{\mu C_{1}}{A_{i}}, \frac{\mu C_{2}}{A_{i}}, \ldots, \frac{\mu C_{n}}{A_{i}}\right\} .
$$


Table 2. The consistency indices of randomly generated reciprocal matrices [11]

\begin{tabular}{|c|c|c|c|c|c|c|c|c|c|c|c|c|c|c|c|}
\hline \multicolumn{16}{|c|}{ Order of the matrix $(n)$} \\
\hline DI & 1 & 2 & 3 & 4 & 5 & 6 & 7 & 8 & 9 & 10 & 11 & 12 & 13 & 14 & 15 \\
\hline $\mathrm{KI}$ & 0.00 & 0.00 & 0.58 & 0.90 & 1.12 & 1.24 & 1.32 & 1.41 & 1.45 & 1.49 & 1.51 & 1.48 & 1.56 & 1.57 & 1.59 \\
\hline
\end{tabular}

The optimal decision for all $(A i) \in A .\left(A^{*}\right)$ is the optimal decision:

$$
\mu_{D}\left(A^{*}\right)=\max \left(\mu_{D},\left(A_{i}\right)\right)
$$

In this approach the importance of criteria is presented as exponential scalars. The rule of thumb being used in this model, the larger should be the exponent gives the minimum rule. Other way round, the less important a criterion is, the smaller weight posses:

$$
\mu_{D}(A)=\min \left\{\left(\mu_{C_{1}}(A)\right)^{a_{1}},\left(\mu_{C_{2}}(A)\right)^{a_{2}}, \ldots,\left(\mu_{C_{n}}(A)\right)^{a_{n}}\right\}
$$

\subsection{Case study}

The MADM techniques are employed to pick up a suitable mining method between main level $+12 \mathrm{~m}$ to level $-227 \mathrm{~m}$, for a lead-zinc-silver mine (Fig. 1) owned by Trepça Joint Stock Company. The underground mine, in which raw lead-zinc-silver of approx 150000 metric tons per year has been exploited, is located in Stan Tërg district of Mitrovica in Kosovo as seen in Figure 2. An underground mining method is requested for Trepça mine by the mine management to extract the ore from deep production stopes utilizing drilling and blasting operation.

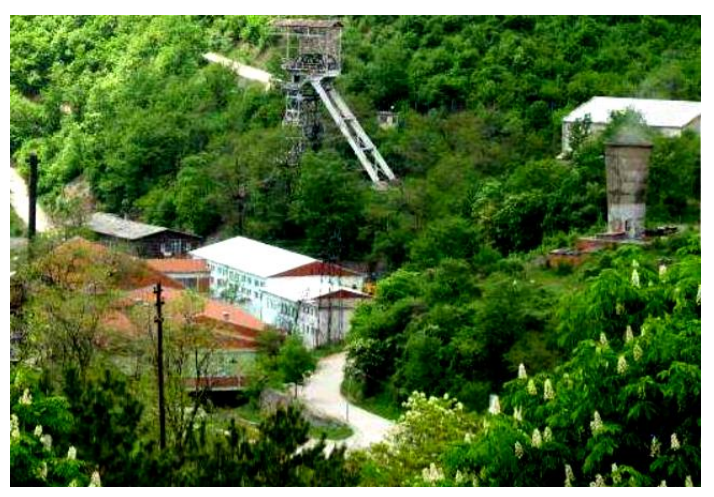

Figure 1. A view of Trepça lead-zinc-silver mine

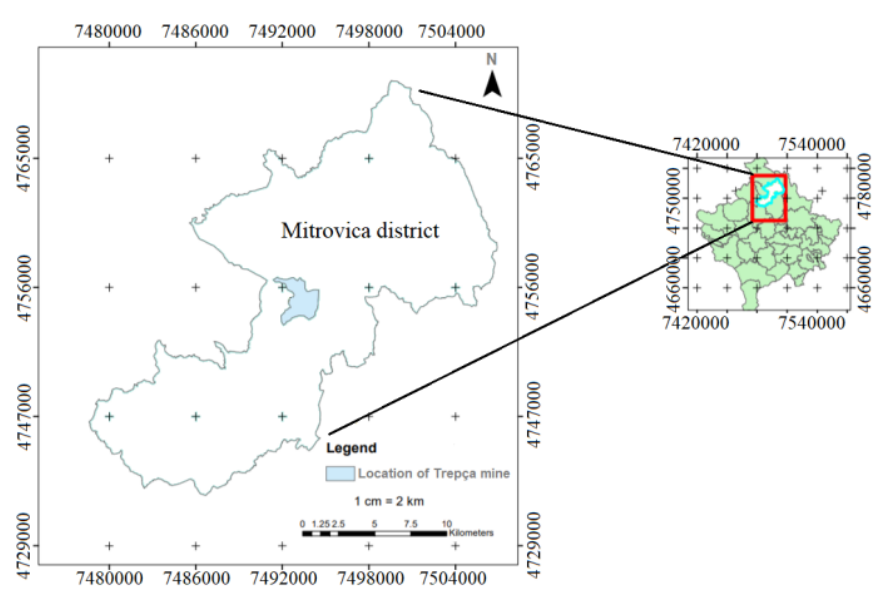

Figure 2. Location map of Trepça mine in Mitrovica district in Kosovo
Trepça mineralization deposit is considered as the largest lead-zinc-silver mine in Kosovo and Europe. The characteristics of the central ore body are tabulated in Table 3, aimed at the use in the UBC tool. The UBC mining method selection tool was developed by [17] and it is an online computer based version of the [18]. This online selection tool is used to determine the best possible alternatives for the ore deposit. A geological cross section view of the central ore body is given in Figure 3, showing the ore body and the surrounding geological rock units in the study area.

Table 3. Main characteristics of the UBC selection tool

\begin{tabular}{lc}
\hline \multicolumn{1}{c}{ Ore deposit characteristics } & Description \\
\hline General shape of deposit & irregular \\
Ore thickness & thick, $30-100 \mathrm{~m}$ \\
Ore plunge & intermediate, $40-45^{\circ}$ \\
Grade distribution & uniform \\
Depth & $>600 \mathrm{~m}$ \\
$\mathrm{RMR}_{1989}$ for deposit & strong \\
$\mathrm{RMR}_{1989}$ for hanging wall & medium \\
$\mathrm{RMR}_{1989}$ for footwall & strong \\
RSS $^{\mathrm{a}}$ for deposit $(>600 \mathrm{~m})$ & very weak \\
$\mathrm{RSS}^{\mathrm{a}}$ for deposit $(>600 \mathrm{~m})$ & very weak \\
RSS $^{\mathrm{a}}$ for deposit $(>600 \mathrm{~m})$ & very weak \\
\hline
\end{tabular}

${ }^{\mathrm{a}} \mathrm{RSS}=\sigma_{c} / \sigma_{v}$

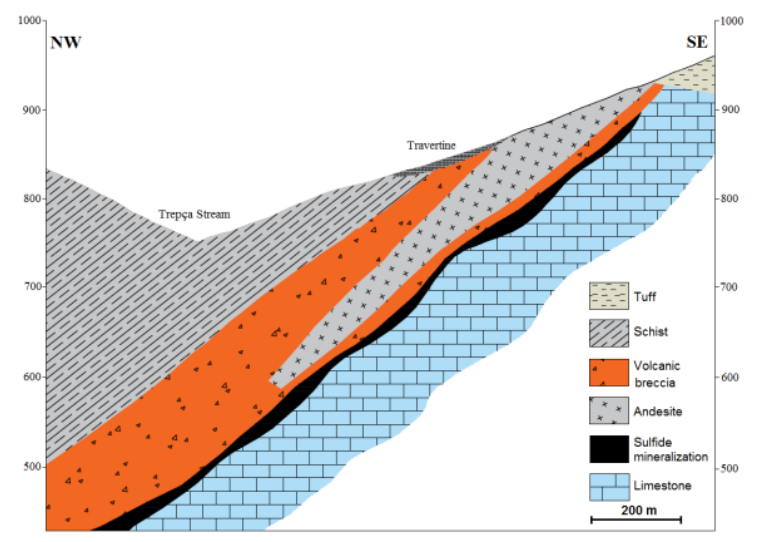

Figure 3. Longitudinal geological cross-section of the central ore body [19])

In this study, rock mass characterization systems such as the Rock Mass Rating (RMR) [20], and the Geological Strength Index (GSI) [21] were utilized to characterize the rock mass and to evaluate the rock mass strength parameters. Results from field studies and observations are presented in Table 4.

Table 4. Rock mass classification ratings for the ore body and surrounding geological units

\begin{tabular}{lcccc}
\hline \multirow{2}{*}{ Classification } & \multicolumn{3}{c}{ Rating range } \\
& $\begin{array}{c}\text { Volcanic } \\
\text { breccias }\end{array}$ & $\begin{array}{c}\text { Sulfide } \\
\text { mineralization }\end{array}$ & Limestone \\
\cline { 1 - 1 } RMR system & $54.6-60.1$ & $65.8-78.5$ & $60.7-70.0$ \\
Mean value & 57.4 & 72.2 & 65.4 \\
GSI system & $55-65$ & $70-80$ & $65-75$ \\
Mean value & 60 & 75 & 70 \\
\hline
\end{tabular}


At the first step, a group of experts must determine the main and sub criteria that will affect the selection of a mining method that can be thought to be optimal for the conditions and requirements of the mine management. All this is done for the sole reason of having a stable productivity and maximum safety during the exploitation process. The main and sub-criteria influencing mining method selection are listed in Table 5.

Table 5. Main and sub-criteria influencing mining method selection

\begin{tabular}{|c|c|c|c|}
\hline \multicolumn{2}{|c|}{ Main criteria } & \multicolumn{2}{|c|}{ Sub-criteria } \\
\hline$\left(\mathrm{C}_{1}\right)$ & $\begin{array}{l}\text { Production } \\
\text { criteria }\end{array}$ & $\begin{array}{l}\left(\mathrm{C}_{11}\right) \\
\left(\mathrm{C}_{12}\right) \\
\left(\mathrm{C}_{13}\right)\end{array}$ & $\begin{array}{c}\text { Mechanization } \\
\text { possibilities } \\
\text { Flexibility } \\
\text { Method } \\
\text { changing }\end{array}$ \\
\hline$\left(\mathrm{C}_{2}\right)$ & $\begin{array}{l}\text { Technological } \\
\text { criteria }\end{array}$ & $\begin{array}{l}\left(\mathrm{C}_{21}\right) \\
\left(\mathrm{C}_{22}\right) \\
\left(\mathrm{C}_{23}\right) \\
\left(\mathrm{C}_{24}\right)\end{array}$ & $\begin{array}{c}\text { Concentration } \\
\text { Selectivity } \\
\text { Ore recovery } \\
\text { Dilution }\end{array}$ \\
\hline$\left(\mathrm{C}_{3}\right)$ & $\begin{array}{l}\text { Management } \\
\text { criteria }\end{array}$ & $\begin{array}{l}\left(\mathrm{C}_{31}\right) \\
\left(\mathrm{C}_{32}\right) \\
\end{array}$ & $\begin{array}{c}\text { Organizations } \\
\text { Safety }\end{array}$ \\
\hline$\left(\mathrm{C}_{4}\right)$ & $\begin{array}{l}\text { Economic } \\
\text { criteria }\end{array}$ & $\begin{array}{l}\left(\mathrm{C}_{41}\right) \\
\left(\mathrm{C}_{42}\right)\end{array}$ & $\begin{array}{c}\text { Investment } \\
\text { cost } \\
\text { Production } \\
\text { cost }\end{array}$ \\
\hline
\end{tabular}

\section{Results and discussion}

The UBC mining method selection tool is applied for quantitative evaluations giving underground mining method alternatives to be valid for the decision-making process. The working principle of the UBC tool is pointing out the rightness of a mining method to the available parameters.

The final rankings based on the UBC selection tool are presented in Figure 4.

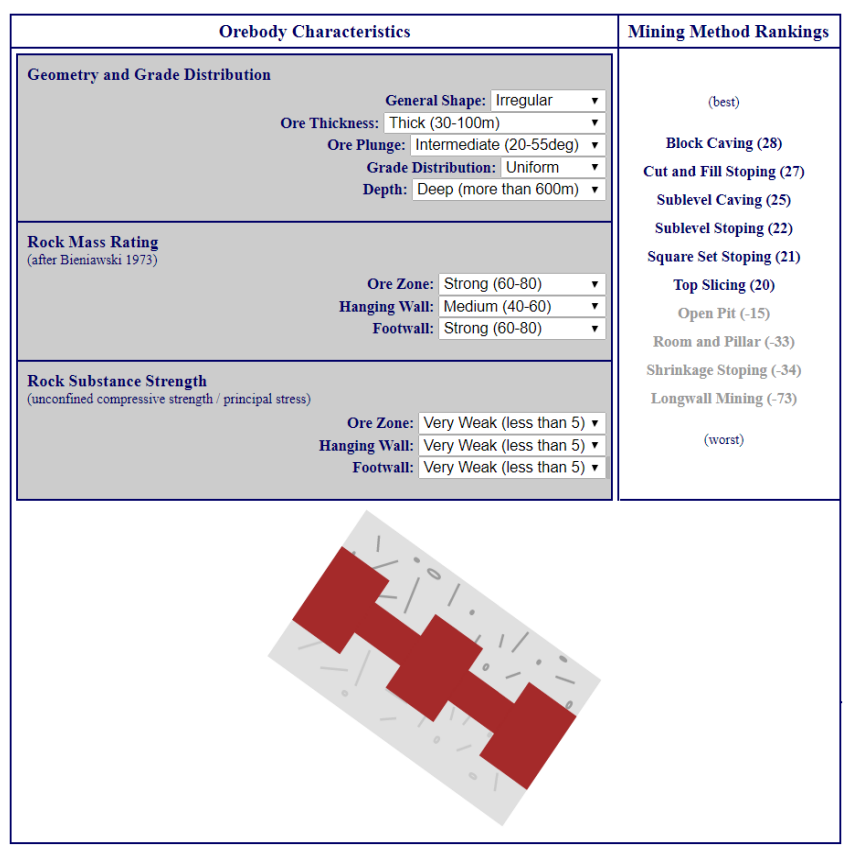

Figure 4. UBC ranking tool for depth $>600 \mathrm{~m}$ at Trepça underground mine ([22])

Figure 4 shows ranking together with scored points for each underground mining method. Nevertheless, since the
UBC technique is adjusted for Canadian hard rock mines so it cannot be precisely suited to Trepça mineral deposit. Applicable alternatives presented in Figure 4, are taken into account or excluded from the alternatives set considering both the rating given for alternatives and engineering experience.

The underground mining method selection process for the mine study area are implemented the AHP and FMADM (Yager's) methods by excluding block caving and square set stoping methods due to the fact that block caving is suitable for massive ore bodies and square set stoping has low productivity rate and high cost.

Prior to commence addressing the problem using the AHP model, the model is organized in a hierarchy fashion composing objective, criteria and alternatives as demonstrated in Figure 5.

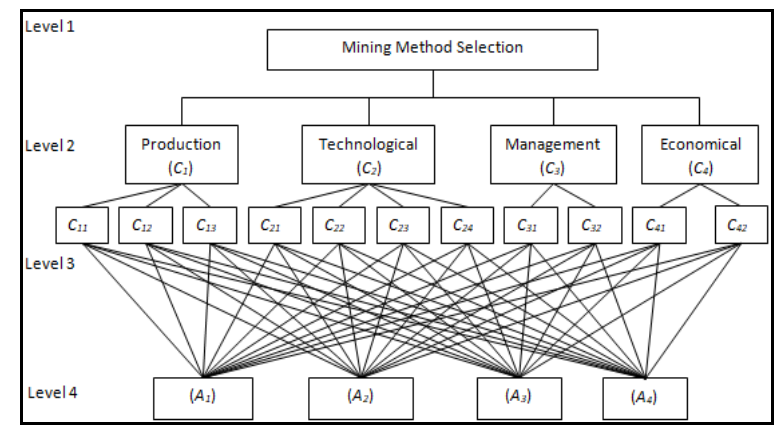

Figure 5. AHP model

Thus, main criteria considered to affect the decisionmaking process are as following; the production, technological, management and economic criteria (Table 5). The main criteria of influence $\left(\mathrm{C}_{1}-\mathrm{C}_{4}\right)$ together with the hierarchy process demonstrated in Figure 5 and with various underground mining methods for the central ore body presented in Figure 4 ought to be the base for the hierarchy process required for the MMS. Afterwards organizing the hierarchy (Fig. 5), the four pair-wise comparison matrices for each level are constructed to compare criteria of influence $\left(\mathrm{C}_{1}-\mathrm{C}_{4}\right)$ on the central ore body.

All main criteria influencing the MMS were compared to each other by the experts, and the PWC matrix was built up as tabulated in Table 6. Afterwards comparing of main criteria, a similar fashion was also conducted for all other subcriteria by the experts and the following comparison matrices given in Tables 6-11 were structured.

Table 6. Pair-wise comparison matrix for main criteria

\begin{tabular}{cccccc}
\hline & $\mathrm{C}_{1}$ & $\mathrm{C}_{2}$ & $\mathrm{C}_{3}$ & $\mathrm{C}_{4}$ & $\mathrm{~W}$ \\
\hline $\mathrm{C}_{1}$ & 1 & 0.33 & 3 & 0.50 & 0.190 \\
$\mathrm{C}_{2}$ & 3 & 1 & 2 & 0.33 & 0.268 \\
$\mathrm{C}_{3}$ & 0.33 & 0.5 & 1 & 0.25 & 0.102 \\
$\mathrm{C}_{4}$ & 2 & 3 & 4 & 1 & 0.440 \\
\hline \multicolumn{5}{c}{$\lambda_{\max }=4.226 ; C R=0.084 \leq 0.1 ; \mathrm{OK}$} & 1.000 \\
\hline
\end{tabular}

Furthermore, the PWC of the alternatives based on each sub-criterion was carried out. Hence, twenty matrices were built up. There exists four alternatives, the matrix order was $4 \times 4$. In this case, the PWC matrix for production is presented in Table 7. Table 7 shows the general priorities considered for the sub-criteria of 'Production' main criterion. Thus, it is clearly noted that the optimal alternative is "Cut-and-Fill Stoping" $\left(\mathrm{A}_{1}\right)$ once judged by the production criterion. 
Table 7. Pair-wise comparison matrix of sub production criterion

\begin{tabular}{ccccc}
\hline & $\mathrm{C}_{11}$ & $\mathrm{C}_{12}$ & $\mathrm{C}_{13}$ & $\mathrm{~W}$ \\
\hline $\mathrm{C}_{11}$ & 1 & 2 & 3 & 0.540 \\
$\mathrm{C}_{12}$ & 0.50 & 1 & 2 & 0.297 \\
$\mathrm{C}_{13}$ & 0.33 & 0.50 & 1 & 0.163 \\
\hline$\lambda_{\max }=3.009 ; C R=0.008 \leq 0.1 ; \mathrm{OK}$ & 1.000 \\
\hline
\end{tabular}

Table 8. Pair-wise comparison matrix of sub management criterion

\begin{tabular}{cccc}
\hline & $\mathrm{C}_{31}$ & $\mathrm{C}_{32}$ & $\mathrm{~W}$ \\
\hline $\mathrm{C}_{31}$ & 1 & 2 & 0.667 \\
$\mathrm{C}_{32}$ & 0.50 & 1 & 0.333 \\
\hline$\lambda_{\max }=2 ;$ & $C R=0 \leq 0.1 ; \mathrm{OK}$ & 1.000 \\
\hline
\end{tabular}

Table 9. Pair-wise comparison matrix of sub-economic criterion

\begin{tabular}{cccc}
\hline & $\mathrm{C}_{41}$ & $\mathrm{C}_{42}$ & $\mathrm{~W}$ \\
\hline $\mathrm{C}_{41}$ & 1 & 0.50 & 0.333 \\
$\mathrm{C}_{42}$ & 2 & 1 & 0.667 \\
\hline$\lambda_{\max }=2 ; C R=0 \leq 0.1 ; \mathrm{OK}$ & 1.000 \\
\hline
\end{tabular}

Table 10. Pair-wise comparison matrix of available alternatives based on sub flexibility criterion

\begin{tabular}{cccccc}
\hline & $\mathrm{A}_{1}$ & $\mathrm{~A}_{2}$ & $\mathrm{~A}_{3}$ & $\mathrm{~A}_{4}$ & $\mathrm{~W}$ \\
\hline $\mathrm{A}_{1}$ & 1 & 3 & 5 & 7 & 0.564 \\
$\mathrm{~A}_{2}$ & 0.33 & 1 & 3 & 5 & 0.263 \\
$\mathrm{~A}_{3}$ & 0.20 & 0.33 & 1 & 3 & 0.118 \\
$\mathrm{~A}_{4}$ & 0.142 & 0.20 & 0.33 & 1 & 0.055 \\
\hline \multicolumn{5}{c}{$\lambda_{\max }=4.117 ; C R=0.043 \leq 0.1 ; \mathrm{OK}$} & 1.000 \\
\hline
\end{tabular}

The overall evaluation of each alternative is estimated by aggregating the product of the relative priority of each criterion and the relative priority of the alternative considering the corresponding criteria. Thus, the overall evaluation of alternative cut-and-fill stoping method is estimated as $(0.467 \cdot 0.540)+(0.564 \cdot 0.297)+(0.472 \cdot 0.163)=0.497$. The last matrix is presented in Table 11. Since the comparisons are based on the subjective evaluation, consistency ratios $(C R)$ were estimated using Equation(4), ensuring the precision choice. Hence, the findings show that the maximum eigenvalues $\left(\lambda_{\max }\right)$ were close to corresponding matrix order and the $(C R)$ values for all calculated matrices were less than 0.10 .

Table 11. Overall results

\begin{tabular}{cccccc}
\hline & $\mathrm{C}_{1}$ & $\mathrm{C}_{2}$ & $\mathrm{C}_{3}$ & $\mathrm{C}_{4}$ & Overall \\
\hline $\mathrm{A}_{1}$ & 0.497 & 0.473 & 0.149 & 0.471 & 0.443 \\
$\mathrm{~A}_{2}$ & 0.275 & 0.240 & 0.238 & 0.242 & 0.247 \\
$\mathrm{~A}_{3}$ & 0.149 & 0.205 & 0.397 & 0.133 & 0.182 \\
$\mathrm{~A}_{4}$ & 0.080 & 0.083 & 0.217 & 0.153 & 0.127 \\
$\mathrm{~W}$ & 0.190 & 0.268 & 0.102 & 0.440 & \\
\hline
\end{tabular}

In Fuzzy MADM model, $\mathrm{A}=\{\mathrm{CFS}, \mathrm{SLC}, \mathrm{SLS}, \mathrm{TS}\}$ represent the possible mining alternatives, whereas, $C=\left\{C_{1}, C_{2}\right.$, $\left.\mathrm{C}_{3}, \mathrm{C}_{4}\right\}$ represent the set of selection criteria. An expert is asked to assign membership level of each criterion in consultation with expert group on this topic. Thus, the membership levels per each criterion are specified by experts utilizing the linguistic model (Fig. 6) and are tabulated in Table 12.

The relevant weights of criteria were finally obtained from the eigenvector matrix. The exponential weighting was consequently defined for each criterion as: $\alpha_{1}=0.102$, $\alpha_{2}=0.056, \alpha_{3}=0.031, \alpha_{4}=0.043, \alpha_{5}=0.075, \alpha_{6}=0.125$, $\alpha_{7}=0.026, \alpha_{8}=0.068, \alpha_{9}=0.034, \alpha_{10}=0.147, \alpha_{11}=0.293$.

Applying the maximum-minimum Bellman and Zadeh principle, final set is calculated as below:
$\mu_{D}(\mathrm{~A})=\left\{\mathrm{A}_{1} / 0.937, \mathrm{~A}_{2} / 0.861, \mathrm{~A}_{3} / 0.765, \mathrm{~A}_{4} / 0.624\right\}$.

The optimal mining method is:

$\mu_{D}\left(\mathrm{~A}^{*}\right)=\max \left(\mu_{D}\left(\mathrm{~A}_{1}\right)\right)=0.937$.

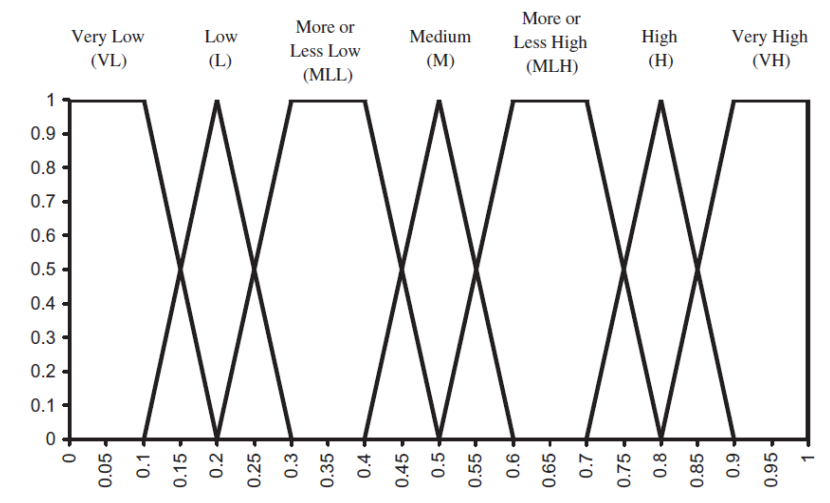

Figure 6. Linguistic model for fuzzy numbers

Table 12. Membership level of each criterion

\begin{tabular}{ccccc}
\hline & $\mathrm{A}_{1}$ & $\mathrm{~A}_{2}$ & $\mathrm{~A}_{3}$ & $\mathrm{~A}_{4}$ \\
\hline$\left(\mathrm{C}_{11}\right)$ & 0.800 & 0.600 & 0.400 & 0.200 \\
$\left(\mathrm{C}_{12}\right)$ & 0.950 & 0.600 & 0.400 & 0.050 \\
$\left(\mathrm{C}_{13}\right)$ & 0.650 & 0.500 & 0.450 & 0.200 \\
$\left(\mathrm{C}_{21}\right)$ & 0.800 & 0.600 & 0.600 & 0.400 \\
$\left(\mathrm{C}_{22}\right)$ & 0.950 & 0.800 & 0.650 & 0.600 \\
$\left(\mathrm{C}_{23}\right)$ & 0.800 & 0.600 & 0.600 & 0.400 \\
$\left(\mathrm{C}_{24}\right)$ & 0.400 & 0.600 & 0.800 & 0.200 \\
$\left(\mathrm{C}_{31}\right)$ & 0.400 & 0.600 & 0.800 & 0.200 \\
$\left(\mathrm{C}_{32}\right)$ & 0.200 & 0.600 & 0.600 & 0.800 \\
$\left(\mathrm{C}_{41}\right)$ & 0.800 & 0.600 & 0.400 & 0.800 \\
$\left(\mathrm{C}_{42}\right)$ & 0.800 & 0.600 & 0.400 & 0.200 \\
\hline
\end{tabular}

The result shows that Cut-and-Fill stoping $\left(A_{1}\right)$ is the optimal mining method.

Understanding sensitivity of each alternative due to changes in criteria sensitivity analysis is taken into account. In the AHP model (Fig. 7), eigenvector component value for each criterion is increased up to $80 \%$ and results no change in the judgement evaluations in the final priority ranking.

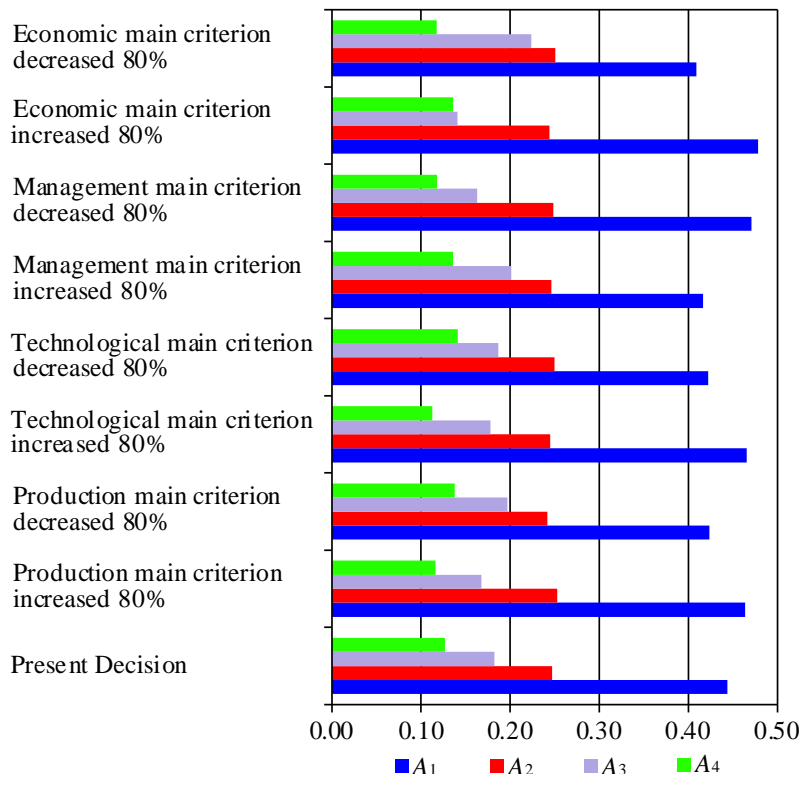

Figure 7. Sensitivity analysis results in the AHP model 
Figure 7 shows that the proposed AHP model is not sensitive to any criteria. In the Yager's model (Fig. 8) results show that alternative $A_{1}$ seems to be sensitive due to economic main criteria as decreased by $43 \%$.

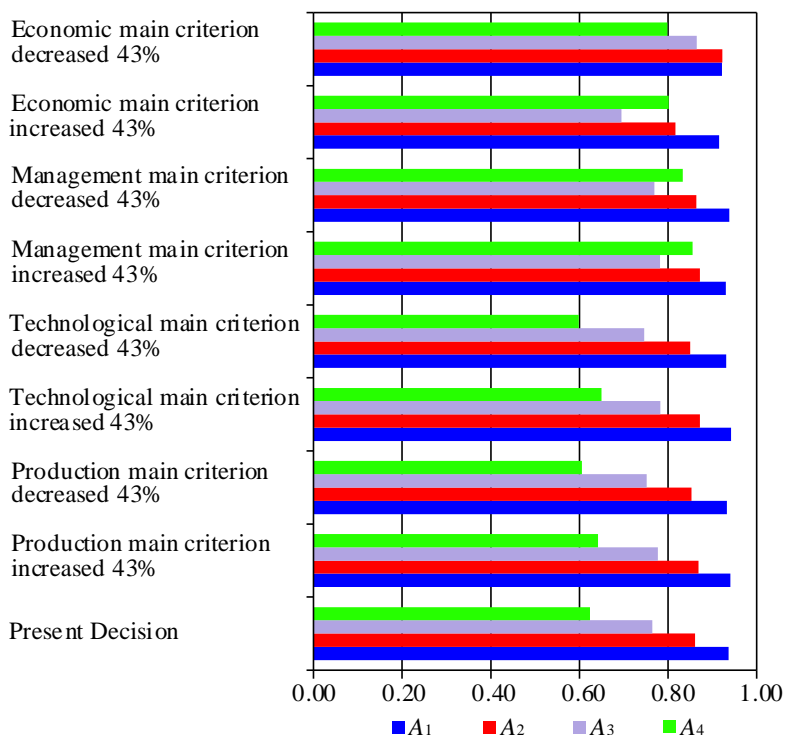

Figure 8. Sensitivity analysis results in the FMADM model

\section{Conclusions}

Mining method selection is a very tough and challenging task due to interaction of several subjective and objective criteria. Hence, experts frequently face difficulties while making decision. In this study, UBC mining method is used to identify a set of reasonable alternatives and two similar MCDM methods were applied to assist experts eliminating issues while making decision on mining method selection. Further, MCDM models containing four main criteria and eleven sub-criteria for four alternatives were developed for this research. However, compared to old methodologies of mining method selection, multi criteria decision making techniques made it possible to select the optimal underground mining method in a scientific fashion that preserved loyalty and objectivity. If MCDM models can be applied accurately, the outcome does not show significant differences between the applied methods (AHP and/or FMADM). Moreover, decision-makers must support their decisions with other methods and should perform sensitivity analyses for giving more accurate decision. In the AHP and Yager's method, results showed that the cut-and-fill stoping method was selected as the optimal underground mining method for the central orebody at Trepça mine.

\section{Acknowledgements}

This study was financially supported by the Scientific Research Project Supporting Commission of Eskişehir Osmangazi University (grant number 201715A238).

\section{References}

[1] Yavuz, M., Iphar, M., \& Once, G. (2008). The optimum support design selection by using AHP method for the main haulage road in WLC Tuncbilek colliery. Tunnelling and Underground Space Technology, 23(2), 111-119. https://doi.org/10.1016/j.tust.2007.02.001

[2] Ataei, M., Jamshidi, M., Sereshki, F., \& Jalali, S.M.E. (2008). Mining method selection by AHP approach. The Journal of The South African Institute of Mining and Metallurgy, (108), 741-749.

[3] Iphar, M., \& Alpay, S. (2018). A mobile application based on multicriteria decision-making methods for underground mining method selection. International Journal of Mining, Reclamation and Environment, 33(7), 480-504. https://doi.org/10.1080/17480930.2018.1467655

[4] Karadogan, A., Bascetin, A., Kahriman, A., \& Gorgun, S. (2001). A new approach in selection of underground mining methods. In International Conference on Modern Management of Mine Producing Geology and Environment Protection (p. 171-183). Bulgaria.

[5] Bitarafan, M.R., \& Ataei, M. (2004). Mining method selection by multiple criteria decision making tools. The Journal of The South African Institute of Mining and Metallurgy, 493-498.

[6] Karadogan, A., Kahriman, A., \& Ozer, U. (2008). Application of fuzzy set theory in the selection of underground mining method. The Journal of The South African Institute of Mining and Metallurgy, (108), 73-79.

[7] Jamshidi, M., Ataei, M., Sereshki, F., \& Jalali, S.M.E. (2009). The application of AHP approach to selection of optimum underground mining method, case study: Jajarm Bauxite Mine (Iran). Achieves of Mining Sciences, 54(1), 103-117.

[8] Alpay, S., \& Yavuz, M. (2009). Underground mining method selection by decision making tools. Tunnelling and Underground Space Technology, 24(2), 173-184. https://doi.org/10.1016/j.tust.2008.07.003

[9] Yavuz, M. (2014). The application of the analytic hierarchy process (AHP) and Yager's method in underground mining method selection problem. International Journal of Mining, Reclamation and Environment, 29(6), 453-475. https://doi.org/10.1080/17480930.2014.895218

[10] Kabwe, E. (2017). Optimal mining method selection for Nchanga's Upper Orebody using analytic hierarchy process and Yager's method. Mining Technology, 126(3), 151-162. https://doi.org/10.1080/14749009.2016.1274840

[11] Saaty, T.L. (2000). Fundamentals of decision making and priority theory with the analytic hierarchy process. Pittsburg, United States: RWS Publications.

[12] Saaty, T.L. (1980). The analytic hierarchy process. New York, United States: McGraw-Hill.

[13] Triantaphyllou, E., \& Sánchez, A. (1997). A sensitivity analysis approach for some deterministic multi-criteria decision-making methods. Decision Sciences, 28(1), 151-194. https://doi.org/10.1111/j.15405915.1997.tb01306.x

[14] Yager, R.R. (1978). Fuzzy decision making including unequal objectives. Fuzzy Sets and Systems, 1(2), 87-95. https://doi.org/10.1016/01650114(78)90010-6

[15] Bellman, R.E., \& Zadeh, L.A. (1970). Decision-making in a fuzzy environment. Management Science, 17(4), 141-164. https://doi.org/10.1287/mnsc.17.4.b141

[16] Zadeh, L.A. (1973). Outline of a new approach to the analysis of complex systems and decision processes. IEEE Transactions on Systems, Man, and Cybernetics, SMC-3(1), 28-44. https://doi.org/10.1109/tsmc.1973.5408575

[17] Miller-Tait, L., Panalkis, R., \& Poulin, R. (1995). UBC mining method selection. Fourth International Symposium on Mine Planning and Equipment Selection. Calgary, Canada.

[18] Nicholas, D.E. (1981). Method selection - a numerical approach, design and operation of caving and sublevel stoping mines. New York, United States: SME-AIME.

[19] Forgan, C.B. (1936). Trepca mines limited II: Essential geological features of the Stan Trg lead-zinc ore body. Mining and Metallurgy, 481-484.

[20] Bieniawski, Z.T. (1989). Engineering rock mass classification. New York, United States: John Wiley \& Sons.

[21] Hoek, E., \& Marinos, P. (2000). Predicting tunnel squeezing problems in weak heterogeneous rock masses. Tunnels and Tunnellig International, $1-21$

[22] EduMine. (1999). Mining method selection (online tool). Retrieved from: http://www.edumine.com/xtoolkit/xmethod/miningmethodgraphic.htm

\section{Оцінка способу підземної розробки із використанням техніки прийняття рішень в умовах невизначеності на прикладі шахти "Трепча", Косово}

\section{Г. Ібіші, М. Явуз, М. Геніс}

Мета. Оцінка ефективності сучасних способів підземної розробки та шарова виїмка із закладкою є адекватним способом для глибокої виїмки на глибинах 800 м і більше на основі теорії прийняття рішень. 
Методика. Були використані наступні способи прийняття рішень: аналітичний ієрархічний процес (АІП), нечіткі багатокритеріальні методи прийняття рішень (НБМПР) і вибір способу розробки методом Університету Британської Колумбії (УБК). При виборі способу розробки методом Університету Британської Колумбії в якості технічно доцільних було виділено 6 можливих варіантів розробки: поверхове обвалення, шарова виїмка із закладкою, підповерхове обвалення, підповерхо-камерна, виїмка із станковим кріпленням і шарове обвалення.

Результати. Розроблено моделі прийняття багатокритеріальних рішень, що містять 4 основні критерії та 11 підкритеріїв для 4 альтернатив, що дозволило в порівнянні зі старими методологіями вибору методів видобутку обрати оптимальний метод підземних гірничих робіт науковим чином, зберігши при цьому лояльність і об'єктивність. Виявлено, що шарова виїмка із закладкою $є$ оптимальним способом розробки на глибоких горизонтах. Так, для шахти “Трепча" даний спосіб підземної розробки є оптимальним, оскільки його ефективність за загальною оцінкою альтернативи $(0.443)$ значно вище, ніж при інших способах розробки.

Наукова новизна. Для умов шахти “Трепча" виявлено найбільш ефективний спосіб підземної розробки на основі методів прийняття рішень АІП і НБМПР.

Практична значимість. При плануванні та проектуванні розробки вибір способу видобутку є найважливішим і часто ризикованим рішенням, яке фахівці повинні прийняти на основі аналізу геологічних, економічних і геотехнічних характеристик рудника.

Ключові слова: спосіб розробки, метод університету Британської Колумбї̈, аналітичний ієрархічний прочес, нечіткий багатокритеріальний метод прийняття рішень, шахта "Трепча"

\section{Оценка способа подземной разработки с использованием техники принятия решений в условиях неопеделенности на примере шахты "Трепча", Косово}

\section{Г. Ибиши, М. Явуз, М. Генис}

Цель. Оценка эффективности современных способов подземной разработки на глубинах 800 м и более на основе теории принятия решений.

Методика. Были использованы следующие способы принятия решений: аналитический иерархический процесс (АИП), нечеткие многокритериальные методы принятия решений (НММПР) и выбор способа разработки методом Университета Британской Колумбии (УБК). При выборе способа разработки методом Университета Британской Колумбии в качестве технически целесообразных было выделено 6 возможных вариантов разработки: этажное обрушение, слоевая выемка с закладкой, подэтажное обрушение, подэтажно-камерная, выемка с креплением станковой крепью и слоевое обрушение.

Результаты. Разработаны модели принятия многокритериальных решений, содержащие 4 основных критерия и 11 подкритериев для 4 альтернатив, что позволило по сравнению со старыми методологиями выбора методов добычи выбрать оптимальный метод подземных горных работ научным образом, сохранив при этом лояльность и объективность. Выявлено, что слоевая выемка с закладкой является оптимальным способом разработки на глубоких горизонтах. Так, для шахты “Трепча" данный способ подземной разработки является оптимальным, так как его эффективность по общей оценки альтернативы (0.443) значительно выше, чем при других способах разработки.

Научная новизна. Для условий шахты “Трепча" выявлен наиболее эффективный способ подземной разработки на основе методов принятия решений АИП и НММПР.

Практическая значимость. При планировании и проектировании разработки, выбор способа добычи является важнейшим и зачастую рискованным решением, которое специалисты должны принять на основе анализа геологических, экономических и геотехнических характеристик рудника.

Ключевые слова: способ разработки, выбор способа разработки методом Университета Британской Колумбии, аналитический иерархический процесс, нечеткий многокритериальный метод принятия решений, шахта "Трепча"

\section{Article info}

Received: 17 April 2020

Accepted: 28 August 2020

Available online: 4 September 2020 